\title{
An Examination on the Recreational Use of Internet by Research Assistants Off-duty or Off-education According to Several Variables
}

\author{
Akgul Beyza Merve*, Goral Senol, Karakucuk Suat \\ Department of Recreation, College of Physical Education and Sports, Gazi University, Turkey
}

Copyright (C) 2016 by authors, all rights reserved. Authors agree that this article remains permanently open access under the terms of the Creative Commons Attribution License 4.0 International License

\begin{abstract}
Internet has a potential that will lead to important changes in our social life and our attitudes, behaviors and habits. Indeed, Internet seems to have started to change a number of social structures from family, friendship to business relationships [1] Internet serves many purposes such as information transfer, academic research, entertainment, communication and commerce. However, extremism in terms of time is observed other than this functional use of Internet. The aim of this study is to assess the recreational use of Internet by research assistants off-duty or off-education according to several variables (gender, civil status, educational level, duration of leisure time, fields, perceived income and perceived leisure time sufficiency, participation in scientific projects, capability of accessing Internet anywhere). 400 research assistants who worked in state universities in Ankara (Gazi, Hacettepe, METU, and Ankara) in the spring term of 2014-2015 participated to the research. The data collection tools are the "Personal Information Form" and the "Addiction Profile Index Internet Form (BAPINT)". BAPINT is about the recreational use of Internet off-duty or off-education (e.g. gaming, social media, e-mailing, websites, chat rooms, forums, etc.) Frequency and percentage calculations, t-test, One-Way ANOVA test were utilized in the analysis and interpretation of the data and the significance level was found to be 0.05 using Tukey's range test to determine the difference between the groups. Consequently, significance differences were found between BAPINT scores of the gender, civil status, educational level, duration of leisure time and perceived leisure time sufficiency variables while no significance difference was found between the BAPINT scores of the variables perceived income, participation in scientific projects, capability of accessing Internet anywhere, and fields.
\end{abstract}

Keywords Internet, Game, Recreation, Research Assistant

\section{Introduction}

In parallel with the rapid progress in computer and communication technologies, Internet's role in how people meet all kinds of their daily needs such as work, shopping, payment, communication, education and entertainment has been increasing day by day. Individuals are able to access all kinds of information they need as fast as possible, instantly get informed of the developments across the world, conduct banking transactions or do shopping [2]. Internet being more easily accessible day by day, offering different purposes and opportunities may increase the time individuals spend on Internet but also cause certain mental and physical drawbacks [3]. Internet addiction is characterized by the fact that the urge to use Internet excessively cannot be prevented, the duration of using Internet cannot be controlled, the time spent on Internet is increasing, over anger and aggressiveness occur when not connected to Internet and individual's social and business life are deteriorating [4-5]. No consensus has been built in the literature on the terms to be used to define the Internet addiction which was considered to be a problem as of 1990s. Internet addiction [4,5], pathological Internet use [6] and problematic Internet use [7] are among the concepts frequently used to define this problem.

The concept of addiction which presents a negative situation can be defined as being unable to quit using or control a substance or a behavior [8]. Addictions that are not dependent on any physical substance can be classified as behavior-based addictions (i.e. eating, gaming, television, shopping, Internet addiction, etc.) [9]. According to Davis [10], healthy use of Internet is defined as using Internet to achieve a goal within an appropriate timeframe without feeling behaviorally uncomfortable. Problematic Internet use is that Internet use causes difficulties in the psychological, social and cognitive areas of individual's life . There is a linear relationship between staying in front of the computer for too long and eating habits, lack of physical activity and increase in obesity [10]. Similarly, it is stated that there is a linear relationship between problematic Internet use and depression, social isolation, loneliness, and decrease in house/school/job performance [10]. Another criterion for Internet addiction is the intended use of Internet. Using 
Internet for online social interactions such as meeting new people, making contact and chatting with individuals with similar interests escalates the effect of addiction $[11,12]$. In the research by Kim and Davis [9] it was found that use of Internet by youngsters or communication with family and friends has little negative effect of their problematic Internet use while using it for meeting new friends has more negative effects on their problematic Internet use. In addition, messaging in chat rooms and sharing experience via messages have been increasingly observed among adolescents [13].

In other words, when used in its intended purpose, Internet is an important technology which enables users to acquire today's important skills such as accessing information, solving problems and self-directed learning. However, when internet is used out of its intended purpose without control and unconsciously, it causes anxiety and fear and may affect the personal development in a negative way [14-15-16-17]. Moreover, excessive Internet use out of its intended purpose may impact user's biological, physiological, psychological and social development negatively [18]. It was also found that increasing duration of Internet use has negative impact on users' general health conditions as well as causing some problems such as depression, isolation, aggressiveness, etc. $[16,19-20]$.

\subsection{Internet as a Recreational Activity}

Recreational activities can be performed in periods of leisure time which can be defined as an episode occurring after the periods of working, sleeping, eating and other compulsory activities and can be also spent as however one wants to [21-22-23,43]. In modern sense, leisure time activities are positive, off-duty activities in which working individuals take pleasure, improve their skills or have fun. Having leisure time and the activities performed during leisure time directly affect other dimensions and values of individuals' lives on the condition of being directly or indirectly [22].

From this point of view, beyond being just a mass medium, Internet seems to have become a phenomenon that organizes communities, shapes individuals' social lives and contributes to their personal developments, inspires and supports academic studies and surrounds the human life. In other words, Internet has apparently begun changing the social structure. An element of the social structure is the leisure time habit. Individuals spend a significant part of their leisure time by gaming or surfing the Internet on the computer today [24]. The time spend on the computer can be considered as making use of leisure time passively.

Today it is almost an inevitable necessity to use Internet. However, it is also an inevitable obligation to determine to what extent this technological miracle has a place in people's life and develop strategies for taking the necessary precautions for the issue. It is seen in the literature that the studies performed to this end have accelerated. Starting from this perspective, the aim of this study is to assess the recreational use of Internet by research assistants who are trained to be the scientists of future off-duty or off-education according to several variables (gender, civil status, educational level, duration of leisure time, fields, perceived income and perceived leisure time sufficiency).

\section{Method}

\subsection{Population and Sample}

The population of the research comprises research assistants who live in Ankara. There are 4597 research assistants who work at the state universities in Ankara. The sample size was calculated with $\mathrm{n}=\mathrm{Nt}^{2} \mathrm{pq} /\left(\mathrm{d}^{2}(\mathrm{~N}-1)+\mathrm{t}^{2} \mathrm{pq}\right)$ [25] and $\mathrm{n}=355$ was found for $\mathrm{N}=4597$ within the reliability range of $95 \%$, d: $0.05 ; \mathrm{t}: 1.96$, taking the $\mathrm{p}$ and $\mathrm{q}$ values as 0.5 each based on the assumption that the research hypothesis would be realized with equal probability under every circumstance. 400 research assistants who worked in state universities in Ankara (Gazi, Hacettepe, METU, and Ankara) in the spring term of 2014-2015 participated to the research. The ages of the research assistants range between 23 and 47, and the average is 28.7. An online version of the questionnaire form developed was prepared, it was sent to the research assistants via e-mail and the volunteers were asked to fill the questionnaire form. 
Table 1. Demographics of the Participants $(\mathrm{N}=400)$

\begin{tabular}{|c|c|c|c|}
\hline & & $\mathrm{N}$ & $\%$ \\
\hline \multirow{2}{*}{ Gender } & Male & 159 & 39.8 \\
\hline & Female & 241 & 60.2 \\
\hline \multirow{2}{*}{ Civil Status } & Single & 264 & 66 \\
\hline & Married & 136 & 34 \\
\hline \multirow{3}{*}{ Educational level } & Postgraduate & 122 & 30.5 \\
\hline & Doctoral Student & 233 & 58.2 \\
\hline & Doctoral Graduate & 45 & 11.2 \\
\hline \multirow{3}{*}{ Perceived Income } & Low & 35 & 8.8 \\
\hline & Moderate & 322 & 80.5 \\
\hline & High & 43 & 10.8 \\
\hline \multirow{5}{*}{ Leisure Time Sufficiency } & Very Insufficient & 54 & 13.5 \\
\hline & Insufficient & 134 & 33.5 \\
\hline & Moderate & 131 & 32.8 \\
\hline & Sufficient & 77 & 19.2 \\
\hline & Very Sufficient & 4 & 1 \\
\hline \multirow{2}{*}{ Personal Talents, Interests } & N/A & 293 & 73.2 \\
\hline & Yes & 107 & 28.8 \\
\hline \multirow{4}{*}{ How Much Leisure Time } & 1-3 Hours & 253 & 62.3 \\
\hline & 4-5 Hours & 118 & 29.5 \\
\hline & 6-7 Hours & 25 & 6.2 \\
\hline & 8 Hours and above & 4 & 1 \\
\hline \multirow{2}{*}{ Capability of Accessing Internet Anytime, Anywhere } & Yes & 378 & 94.5 \\
\hline & No & 22 & 5.5 \\
\hline \multirow{3}{*}{ Fields } & Social Sciences & 193 & 48.2 \\
\hline & Sciences & 142 & 35.5 \\
\hline & Health Sciences & 65 & 16.2 \\
\hline
\end{tabular}

\subsection{Data Collection Tool}

The questionnaire used to collect data is composed of two parts. These are the "Personal Information Form" and the "Addiction Profile Index Internet Form (BAPINT)". Demographical questions were asked in the personal information form about gender, age, perceived income, perceived leisure time sufficiency, duration of leisure time, etc. The Addiction Profile Index Internet Form (BAPINT) is a 5-subdimension, 18-item scale developed by [26] BAPINT is about the recreational use of Internet off-duty or off-education (e.g. gaming, social media, e-mailing, websites, chat rooms, forums, etc.) Therefore, it was found to be suitable for being used in this study. The questions cover the last three months. It has 5 subdimensions: frequency of Internet usage, diagnosis, impacts on life, strong urge and motivation. BAPINT's sensitivity is 0.90 and specificity is 0.90 at the breakpoint over 2 points (PPV: 99.1 NPV: 61.5) [44]. Cronbach's Alpha coefficient for the whole scale was found to be 0.88 . Cronbach's Alpha coefficient was found to be 0.88 again in this study.

\subsection{Analysis of Data}

Frequency and percentage calculations were made for the demographics of the research group. The distributions of the variables according to the groups were examined, and it was concluded evaluating the normality of the distributions and the homogeneity of the variances that the distributions did exhibit parametric quality. Hence, revealing the descriptive statistics of the use of Internet by the research assistants, t-test was conducted to examine whether their BAPINT 
levels varied according to gender, civil status, participation in scientific projects, capability of accessing Internet anywhere while One-Way ANOVA was used according to fields, educational level, duration of leisure time, perception of leisure time sufficiency and perceived income. When multiple variables were examined, Tukey's range test was applied for the significant difference to determine between which groups that difference was. The significance level for the statistical analyses was accepted as 0.05 .

\section{Results}

When participants' frequencies of recreational (e.g. gaming, social media, e-mailing, websites, chat rooms, forums, etc.) Internet usage off-duty or off-education were examined, $42 \%(n=169)$ of them used Internet for $4-5$ hours daily; $23 \%(n=91)$ for 6 hours and more; $15 \%(n=60)$ of them for $1-3$ hours; $5 \%(n=20)$ of them for less than 1 hour; and $1 \%(\mathrm{n}=3)$ of them 1-5 times a week. It is seen that most of the participants used Internet for recreational purposes quite a bit. As for the answers given by the participants to the questions, about half (43.5\%) of them reported that the time they spent on Internet "usually" increased while 39\% of them thought that the time they spent on Internet was "usually" too much. Besides, majority $(66.5 \%)$ of the participants reported that their family and people around them "rarely" worried about them using too much Internet.

BAPINT's sensitivity is 0.90 and specificity is 0.90 at the breakpoint over 2 points (PPV: 99.1 NPV: 61.5). Accordingly, it is seen that there were $\mathrm{n}=305 \quad(76.2 \%)$ research assistants above the breakpoint in the study. $23.8 \%$ $(n=95)$ of the research assistants were under the breakpoint. The addiction severity of the majority is accordingly above the breakpoint.

According to the results of the ANOVA performed to test participants' BAPINT scores and subdimensions based on their fields (sciences, social and health sciences), there is no significant difference statistically between their fields and BAPINT scores. According to the results of the ANOVA performed to test participants' BAPINT scores and subdimensions based on perceived income level (very low, low, moderate, high, very high), there is no significant difference statistically between their perceived income levels and BAPINT scores. Similarly, based on the results of the ANOVA performed to test participants' BAPINT scores and subdimensions based on participation in scientific projects and capability of accessing Internet anywhere, there is no significant difference statistically between the two variables and BAPINT scores.

The tables including the results with statistically significant differences are given below.

According to the results of the t-test performed to test participants' BAPINT scores and subdimensions based on gender, there is a statistically significant difference between female and male participants' BAPINT scores and in the impacts on life subdimension $[\mathrm{t}(398)=; \mathrm{p}<0.05]$. Male participants' BAPINT scores $(2.54 \pm 0.57)$ are higher that female participants' BAPINT scores $(2.38 \pm 0.65)$. The situation is similar for the impacts on life subdimension of the BAPINT scale. Male participants' scores $(1.82 \pm 0.60)$ are higher that female participants' scores $(1.63 \pm 0.56)$. In other words, male participants' levels of recreational Internet use are higher than male participants' levels.

Table 2. Comparison of Participants' BAPINT scores and subdimensions according to gender

\begin{tabular}{|c|c|c|c|c|c|c|c|}
\hline & Gender & $\mathrm{N}$ & $\bar{x}$ & ss & sd & $\mathrm{t}$ & $\mathrm{p}$ \\
\hline \multirow{2}{*}{ Frequency of Internet usage } & Male & 159 & 4.38 & 0.95 & \multirow{2}{*}{398} & \multirow{2}{*}{1.91} & \multirow{2}{*}{.06} \\
\hline & Female & 241 & 4.17 & 1.15 & & & \\
\hline \multirow{2}{*}{ Diagnosis } & Male & 159 & 2.46 & 0.66 & \multirow{2}{*}{398} & \multirow{2}{*}{1.05} & \multirow{2}{*}{.30} \\
\hline & Female & 241 & 2.38 & 0.74 & & & \\
\hline \multirow{2}{*}{ Effects on life } & Male & 159 & 1.82 & 0.60 & \multirow{2}{*}{398} & \multirow{2}{*}{3.3} & \multirow{2}{*}{$0 *$} \\
\hline & Female & 241 & 1.63 & 0.56 & & & \\
\hline Strong urge & Male & 159 & 2.04 & 0.89 & \multirow[t]{2}{*}{398} & \multirow[t]{2}{*}{1.92} & \multirow[t]{2}{*}{.06} \\
\hline \multirow{3}{*}{ Motivation } & Female & 241 & 1.86 & 0.93 & & & \\
\hline & Male & 159 & 2 & 0.88 & \multirow[t]{2}{*}{398} & \multirow[t]{2}{*}{1.38} & \multirow[t]{2}{*}{.17} \\
\hline & Female & 241 & 1.87 & 0.88 & & & \\
\hline \multirow{2}{*}{ BAPINT TOTAL } & Male & 159 & 2.54 & 0.57 & \multirow{2}{*}{398} & \multirow{2}{*}{2.48} & \multirow{2}{*}{$.01^{*}$} \\
\hline & Female & 241 & 2.38 & 0.65 & & & \\
\hline
\end{tabular}

$* \mathrm{p}<0.05$ 
Table 3. Comparison of Participants' BAPINT scores and subdimensions according to civil status

\begin{tabular}{|c|c|c|c|c|c|c|c|}
\hline & Civil Status & $\mathrm{N}$ & $\bar{x}$ & ss & sd & $\mathrm{t}$ & $\mathrm{p}$ \\
\hline \multirow{2}{*}{ Frequency of Internet usage } & Single & 264 & 4.40 & 1.04 & \multirow{2}{*}{398} & \multirow{2}{*}{3.33} & \multirow{2}{*}{$.00 *$} \\
\hline & Married & 136 & 4.01 & 1.11 & & & \\
\hline \multirow{2}{*}{ Diagnosis } & Single & 264 & 2.53 & 0.71 & \multirow{2}{*}{398} & \multirow{2}{*}{4.50} & \multirow{2}{*}{$.00 *$} \\
\hline & Married & 136 & 2.20 & 0.67 & & & \\
\hline \multirow{2}{*}{ Effects on life } & Single & 264 & 1.80 & 0.61 & \multirow{2}{*}{398} & \multirow{2}{*}{3.73} & \multirow{2}{*}{$.00 *$} \\
\hline & Married & 136 & 1.57 & 0.50 & & & \\
\hline \multirow{2}{*}{ Strong urge } & Single & 264 & 2 & 0.95 & \multirow{2}{*}{398} & \multirow{2}{*}{1.80} & \multirow{2}{*}{.07} \\
\hline & Married & 136 & 1.82 & 0.86 & & & \\
\hline \multirow{2}{*}{ Motivation } & Single & 264 & 2.05 & 0.90 & \multirow{2}{*}{398} & \multirow{2}{*}{4.18} & \multirow{2}{*}{$.00 *$} \\
\hline & Married & 136 & 1.68 & 0.80 & & & \\
\hline \multirow{2}{*}{ BAPINT TOTAL } & Single & 264 & 2.55 & 0.64 & \multirow{2}{*}{398} & \multirow{2}{*}{4.60} & \multirow{2}{*}{$.00 *$} \\
\hline & Married & 136 & 2.25 & 0.56 & & & \\
\hline
\end{tabular}

$* \mathrm{p}<0.05$

According to the results of the t-test performed to test participants' BAPINT scores and subdimensions based on civil status, there is a statistically significant difference between female and male participants' BAPINT scores and in the frequency of Internet usage, diagnosis, impacts on life and motivation subdimensions $[\mathrm{t}(398)=; \mathrm{p}<0.05]$. In the BAPINT scale scores and all subdimensions, single participants' BAPINT scores are higher than married participants' scores. In other words, single research assistants' levels of recreational Internet use are higher than married research assistants' levels.

Table 4. Comparison of Participants' BAPINT scores and subdimensions according to educational level

\begin{tabular}{|c|c|c|c|c|c|c|}
\hline & Education Level & $\mathrm{N}$ & $\bar{x}$ & ss & $\mathrm{F}$ & $\mathrm{p}$ \\
\hline \multirow{3}{*}{ Frequency of Internet usage } & Postgraduate & 122 & 4.32 & 1.04 & \multirow{3}{*}{1.54} & \multirow{3}{*}{.216} \\
\hline & Doctoral student & 233 & 4.28 & 1.11 & & \\
\hline & Doctoral graduate & 45 & 4 & 1.13 & & \\
\hline \multirow{3}{*}{ Diagnosis } & Postgraduate & 122 & 2.47 & 0.63 & \multirow{3}{*}{6.23} & \multirow{3}{*}{$.002 *$} \\
\hline & Doctoral student & 233 & 2.45 & 0.74 & & \\
\hline & Doctoral graduate & 45 & 2.07 & 0.72 & & \\
\hline \multirow{3}{*}{ Effects on life } & Postgraduate & 122 & 1.75 & 0.56 & \multirow{3}{*}{1.67} & \multirow{3}{*}{.191} \\
\hline & Doctoral student & 233 & 1.72 & 0.62 & & \\
\hline & Doctoral graduate & 45 & 1.56 & 0.52 & & \\
\hline \multirow{2}{*}{ Strong urge } & Postgraduate & 122 & 1.94 & 0.89 & \multirow{2}{*}{0.06} & \multirow{2}{*}{.939} \\
\hline & Doctoral graduate & 45 & 1.89 & 0.95 & & \\
\hline \multirow{3}{*}{ Motivation } & Postgraduate & 122 & 2.08 & 0.94 & \multirow{3}{*}{6.68} & \multirow{3}{*}{$.001 *$} \\
\hline & Doctoral student & 233 & 1.92 & 0.88 & & \\
\hline & Doctoral graduate & 45 & 1.52 & 0.63 & & \\
\hline \multirow{3}{*}{ BAPINT TOTAL } & Postgraduate & 122 & 2.51 & 0.60 & \multirow{3}{*}{4} & \multirow{3}{*}{$.019^{*}$} \\
\hline & Doctoral student & 233 & 2.47 & 0.65 & & \\
\hline & Doctoral graduate & 45 & 2.21 & 0.58 & & \\
\hline
\end{tabular}

$* \mathrm{p}<0.05$

According to the results of the ANOVA performed to test participants' BAPINT scores and the subdimensions based on educational level, there is a statistically significant difference between educational levels and BAPINT scores $[F()=4$; $\mathrm{p}<0.05]$, the diagnosis $[\mathrm{F}(2.397)=6.23 ; \mathrm{p}<0.05]$ and motivation $[\mathrm{F}(2.397)=6.68 ; \mathrm{p}<0.05]$ subdimensions. According to the results of Tukey's range test to find between which groups this difference was, doctoral graduate participants' BAPINT scores are higher than the scores of the participants who are postgraduates and doctoral students $(p<0.05)$. In other words, as the educational level goes up, participants' levels of recreational Internet usage increase too. 
Table 5. Comparison of Participants' BAPINT scores and subdimensions according to duration of leisure time

\begin{tabular}{|c|c|c|c|c|c|c|}
\hline & $\begin{array}{c}\text { Duration of } \\
\text { Leisure Time }\end{array}$ & $\mathrm{N}$ & $\bar{x}$ & ss & $\mathrm{F}$ & $\mathrm{p}$ \\
\hline \multirow{4}{*}{ Frequency of Internet usage } & 1-3 hours & 253 & 4.13 & 1.12 & \multirow{4}{*}{3.79} & \multirow{4}{*}{$.011 *$} \\
\hline & 4-5 hours & 118 & 4.45 & 0.97 & & \\
\hline & 6-7 hours & 25 & 4.64 & 1.03 & & \\
\hline & 8 hours and above & 4 & 4.75 & 0.50 & & \\
\hline \multirow{4}{*}{ Diagnosis } & 1-3 hours & 253 & 2.34 & 0.70 & \multirow{4}{*}{5.69} & \multirow{4}{*}{$.001 *$} \\
\hline & 4-5 hours & 118 & 2.45 & 0.67 & & \\
\hline & 6-7 hours & 25 & 2.90 & 0.78 & & \\
\hline & 8 hours and above & 4 & 2.92 & 0.88 & & \\
\hline \multirow{4}{*}{ Effects on life } & 1-3 hours & 253 & 1.65 & 0.52 & \multirow{4}{*}{4.70} & \multirow{4}{*}{$.003^{*}$} \\
\hline & 4-5 hours & 118 & 1.76 & 0.66 & & \\
\hline & 6-7 hours & 25 & 2.08 & 0.73 & & \\
\hline & 8 hours and above & 4 & 1.71 & 0.63 & & \\
\hline \multirow{4}{*}{ Strong urge } & 1-3 hours & 253 & 1.84 & 0.89 & \multirow{4}{*}{4.53} & \multirow{4}{*}{$.004 *$} \\
\hline & 4-5 hours & 118 & 2.03 & 0.91 & & \\
\hline & 6-7 hours & 25 & 2.48 & 1.15 & & \\
\hline & 8 hours and above & 4 & 1.75 & 0.65 & & \\
\hline \multirow{4}{*}{ Motivation } & 1-3 hours & 253 & 1.83 & 0.84 & \multirow{4}{*}{3.89} & \multirow{4}{*}{$.009 *$} \\
\hline & 4-5 hours & 118 & 2.02 & 0.94 & & \\
\hline & 6-7 hours & 25 & 2.36 & 0.90 & & \\
\hline & 8 hours and above & 4 & 2.37 & 0.85 & & \\
\hline \multirow{4}{*}{ BAPINT TOTAL } & 1-3 hours & 253 & 2.36 & 0.60 & \multirow{4}{*}{7.37} & \multirow{4}{*}{$.000^{*}$} \\
\hline & 4-5 hours & 118 & 2.54 & 0.62 & & \\
\hline & 6-7 hours & 25 & 2.89 & 0.73 & & \\
\hline & 8 hours and above & 4 & 2.70 & 0.39 & & \\
\hline
\end{tabular}

$* \mathrm{p}<0.05$

According to the results of the ANOVA performed to test participants' BAPINT scores and the subdimensions based on duration of leisure time, there is a statistically significant difference between duration of leisure time and BAPINT scores and all subdimensions $(\mathrm{p}<0.05)$. According to the results of Tukey's range test to find between which groups this difference was, BAPINT scores of the participants who had 1-3 hours of leisure time are higher than those who had 4-5 hours of leisure time for the frequency of Internet usage subdimension of the BAPINT scale. BAPINT scores of the participants who had 6-7 hours of leisure time are higher than those who had 8 hours of leisure time and above. For the diagnosis subdimension of the BAPINT scale, scores of the participants who had 1-2 hours of leisure time are higher than those who had 6-7 hours of leisure time while scores of the participants who had 4-5 hours of leisure time are higher than those who had 6-7 hours of leisure time. Similarly, for the impacts on life, strong urge and motivation subdimensions of the BAPINT scale, scores of the participants who had 1-3 hours of leisure time are higher than those who had 6-7 hours of leisure time. In short, it can be said that the levels of recreational Internet usage decreased as the leisure time that the research assistants had increased, or the research assistants who had less leisure time have higher levels of recreational Internet usage. 
Table 6. Comparison of Participants' BAPINT scores and subdimensions according to leisure time sufficiency

\begin{tabular}{|c|c|c|c|c|c|c|}
\hline & Leisure time sufficiency & $\mathrm{N}$ & $\bar{x}$ & ss & $\mathrm{F}$ & $\mathrm{p}$ \\
\hline \multirow{5}{*}{ Frequency of Internet usage } & Very insufficient & 54 & 4.20 & 1.25 & \multirow{5}{*}{2.73} & \multirow{5}{*}{$.029 *$} \\
\hline & Insufficient & 134 & 4.07 & 1.12 & & \\
\hline & Moderately & 131 & 4.41 & 0.95 & & \\
\hline & Sufficient & 77 & 4.34 & 1.05 & & \\
\hline & Very sufficient & 4 & 5.25 & 0.96 & & \\
\hline \multirow{5}{*}{ Diagnosis } & Very insufficient & 54 & 2.31 & 0.61 & \multirow{5}{*}{2.32} & \multirow{5}{*}{.056} \\
\hline & Insufficient & 134 & 2.33 & 0.73 & & \\
\hline & Moderately & 131 & 2.51 & 0.75 & & \\
\hline & Sufficient & 77 & 2.44 & 0.63 & & \\
\hline & Very sufficient & 4 & 3.08 & 0.97 & & \\
\hline \multirow{5}{*}{ Impacts on life } & Very insufficient & 54 & 1.60 & 0.56 & \multirow{5}{*}{3.96} & \multirow{5}{*}{$.004 *$} \\
\hline & Insufficient & 134 & 1.63 & 0.53 & & \\
\hline & Moderately & 131 & 1.83 & 0.62 & & \\
\hline & Sufficient & 77 & 1.68 & 0.56 & & \\
\hline & Very sufficient & 4 & 2.39 & 0.98 & & \\
\hline \multirow{5}{*}{ Strong urge } & Very insufficient & 54 & 1.68 & 0.86 & \multirow{5}{*}{2.73} & \multirow{5}{*}{$.029 *$} \\
\hline & Insufficient & 134 & 1.88 & 0.87 & & \\
\hline & Moderately & 131 & 2.02 & 0.97 & & \\
\hline & Sufficient & 77 & 2.02 & 0.94 & & \\
\hline & Very sufficient & 4 & 2.87 & 0.85 & & \\
\hline \multirow{5}{*}{ Motivation } & Very insufficient & 54 & 1.83 & 0.84 & \multirow{5}{*}{0.80} & \multirow{5}{*}{.539} \\
\hline & Insufficient & 134 & 2.02 & 0.94 & & \\
\hline & Moderately & 131 & 2.36 & 0.90 & & \\
\hline & Sufficient & 77 & 2.37 & 0.85 & & \\
\hline & Very sufficient & 4 & & & & \\
\hline \multirow{5}{*}{ BAPINT TOTAL } & Very insufficient & 54 & 2.33 & 0.57 & \multirow{5}{*}{3.70} & \multirow{5}{*}{$.006^{*}$} \\
\hline & Insufficient & 134 & 2.35 & 0.62 & & \\
\hline & Moderately & 131 & 2.56 & 0.66 & & \\
\hline & Sufficient & 77 & 2.48 & 0.60 & & \\
\hline & Very sufficient & 4 & 3.15 & 0.78 & & \\
\hline
\end{tabular}

$* \mathrm{p}<0.05$

According to the results of the ANOVA performed to test participants' BAPINT scores and the subdimensions based on duration of leisure time, there is a statistically significant difference between leisure time sufficiency and BAPINT scores and the frequency of Internet usage, impacts on life and strong urge subdimensions $(\mathrm{p}<0.05)$. According to the results of Tukey's range test to find between which groups this difference was, BAPINT scores of the participants who had insufficient leisure time are higher than those who had moderately and very sufficient leisure time for the frequency of Internet usage subdimension of the BAPINT scale. For the impacts on life subdimension of the BAPINT scale, BAPINT scores of the participants who had very insufficient leisure time are higher than those who had moderately and very sufficient leisure time; and scores of those who had insufficient leisure time are higher than those who had moderately and very sufficient leisure time while BAPINT scores of the participants who had sufficient leisure time are higher than those who had very sufficient leisure time.

Similarly, for the strong urge subdimension of the BAPINT scale, BAPINT scores of the participants who had very insufficient leisure time are higher than those who had moderately sufficient, sufficient and very sufficient, scores of the participants who had insufficient leisure time are higher than those who had very sufficient leisure time. In other words, as the perceived leisure time sufficiency decreases, participants' levels of recreational Internet usage increase.

\section{Discussion}

In this study, the aim is to assess the recreational use of 
Internet by research assistants who are trained to be the scientists of future off-duty or off-education according to several variables (gender, civil status, educational level, duration of leisure time, participation in scientific projects, capability of accessing Internet anywhere, perceived income and perceived leisure time sufficiency). Accordingly, based on perception of leisure time sufficiency, that is, whether individuals regard their leisure time sufficient or insufficient, when the BAPINT scores are examined, as leisure time insufficiency increased, recreational use of Internet increases too. In other words, the participants who perceived their leisure time as insufficient or very insufficient spent more time on Internet for recreational purposes (gaming, social media, e-mailing, websites, chat room, forums, etc.) Another finding which is parallel with this one is the assessment of BAPINT scores according to duration of leisure time. Accordingly, research assistants' levels of recreational Internet usage increased as duration of leisure time decreased. These two findings show that the research produced consistent data in itself. They are also quite interesting by the way. This may be explained by the rapid development in Internet and the fact that Internet is becoming more accessible and cheap day by day. Almost all research assistants (95\%) participated in the research have the opportunity to access Internet anytime and anywhere. Due to easy Internet access in university campuses and relatively flexible schedules of the research participants, use of Internet has become widespread [27]

Psychological and environmental factors in individuals' lives may cause them to experience Internet addiction [28] and Internet may become an option for many people [28]. On the other hand, Internet serves as an important medium both qualitative and quantitative development of individuals' social lives today because it provides the opportunity to be omnipresent and establish rapid connections [29]. However, there are drawbacks when Internet is used excessively. Ögel [24] summarize the situation as "Chocolate is delicious but a kilo of chocolate is dangerous."

$73 \%$ of the research assistants reported that they do not have any personal talents or interest to make use of or get busy with during their leisure time. In this sense, it can be regarded as quite natural that the research assistants, majority of which are in the moderate and low income group and who consider their leisure time as insufficient, find easily accessible, fast and cheap Internet as a recreational activity. Internet is considered as a new medium to make use of leisure time today, and to some people, Internet is a medium in which one can enjoy their time [30]. Whoever hear the word Internet naturally thinks that it is some kind of entertaining tool. Mass media mention about the content of Internet generally as entertainment and liberation [30]. According to the data from TSI (2014), as for the individuals' personal intended use of Internet for the past three months, $79 \%$ of them used Internet for joining in social groups (Facebook, Twitter, etc.) and $60 \%$ of them used it for downloading/playing games, music, movie and images. In a study performed with university instructors, those who use
Internet everyday constitute the majority with $57.5 \% .35 \%$ of the participants reported that they use it 2-3 times a week. Based on these findings, it can be said that instructors often benefit from Internet [31]. In addition, about half (43.5\%) of the research participants reported that the time they spent on Internet "usually" increased while $39 \%$ of them thought that the time they spent on Internet was "usually" too much. It can be said that the research assistants have awareness about this matter.

When BAPINT scores are examined according to the gender variable in the study, male participants' levels of recreational Internet use are higher than male participants' levels. Previous research found that males spend most of their times playing computer games and females reading and spending time with their friends [32]. Moreover, potentially, majority of computer games are basically designed for the male market. Studies show that male brain is activated more and faster by gaming [24]. This seems to be parallel with our study. In another study, as for the distribution of the relationship between instructors' gender and their frequencies of using Internet, no significant difference was found between the two elements and it was reported that the rate of male instructors "always" using Internet was $11.4 \%$ and higher than female instructors' rate (5.5\%) [32]. There are studies achieving similar results. The studies show that there are important predictors of using Internet rather for social interaction and entertainment purposes such as establishing social relations, shopping, downloading movies and songs, playing online games [6,9,11,33-34-35-36] and male's [6,33,35-36-37-38-39-40] problematic use of Internet. According to the data from Turkish Statistical Institute (TSI) (2014) [41], as for the individuals' personal intended use of Internet for the past three months, both male $(83 \%)$ and female $(77 \%)$ participants used Internet for joining in social groups (Facebook, Twitter, etc.) at the highest rate.

Another finding is the examination of BAPINT scores according to civil status. Accordingly, single research assistants' levels of recreational Internet use are higher than married research assistants' levels. It can be said that single research assistants used Internet which is one of the leisure time activities more often since they do not have any family responsibilities (sparing time for spouse, children, helping with the household work, family responsibilities, etc.) Another study achieved similar results. Accordingly, no significant difference was found between civil statuses and whether benefiting from Internet, and single participants "always" and "often" benefited from Internet at high rates compared to the married ones. The rate of those who reported that they never use Internet is higher among the married participants. It was also determined that married participants' rates of using Internet "sometimes" and "rarely" was higher than the single participants [32]. On the other hand, the difference in the Internet use among single problematic Internet users seems to be found in their lack of ability in maintaining satisfactory relationships [27, 45]. Moreover, research also found that adults with an increased level of emotional loneliness and lack of interpersonal 
relationships are likely to use the Internet [46, 47]. Based on these findings, the use 9 of the Internet among adults is likely to be linked with reducing their sense of loneliness. The interpersonal motivation of Internet use was supported by Young's [48]. Qualitative study interviewed 35 counselors working with problematic Internet users. In the study, most $(91 \%)$ of the counselors reported that their clients used the Internet for the purpose of seeking new relationships. Seventy four percent of the participant counselors reported they helped their clients with solving relational issues [49].

When BAPINT scores of the research assistants according to their educational levels are examined, BAPINT scores of the research assistants who are doctoral graduates are higher than postgraduates and doctoral students. As the educational level goes up, participants' levels of recreational Internet usage increase too. It was stated in previous research that using frequency of Internet users is closely related to the educational level. Individuals with higher educational level use Internet more. The researches by Yıldız and Bölükbaş [30] support this opinion. According to the 2011 results of Alternative Informatics Association[42], computer and Internet usage rates get higher as the educational level increases regardless of gender. However, it should be also noted that females use Internet less than males on every educational level. According to the educational levels in the Household IT Usage Research conducted by Turkish Statistical Institute (TSI) on 16-74 age group in Turkey, those who use computer and Internet most were postgraduates, undergraduates and above [41.]

As for BAPINT scores of the research assistants according to income level, no statistically significant difference was found. Likewise, there was no statistically significant difference in BAPINT scores of the research assistants according to their fields. It can be said that the reason is the research assistants are a homogenous group and $81 \%$ of them perceive their income level as moderate. In the study conducted by the Ministry of Health to investigate the Internet addiction, the rate of Internet addiction is higher in urban areas and on the moderate income level. It was found that the addiction level gets higher as the income level increases. In this sense, it is thought that Internet addiction may pose a problem for the sample group of this research. According to the 2023 projection in the same research, it was explained that the addiction rate is expected to be $24.6 \%$.

Consequently, the addiction severity of the majority $(\mathrm{n}=305,76.2 \%)$ is accordingly above the breakpoint. In addition, significance differences were found between BAPINT scores of the gender, civil status, educational level, duration of leisure time and perceived leisure time sufficiency variables while no significance difference was found between the BAPINT scores of the variables perceived income and fields. In other words, it is seen that the tendency and urge of research assistants to use Internet for passive recreational activities like gaming, etc. off-duty and off-education increased. This shows that future scientists may encounter with physical and psychological problems in their lives or deficiencies in their academic studies due to moving towards Internet addition even if it is yet to be completely defined. Therefore, what should be looked for is how research assistants can make use of their leisure time and the way to gather them with sportive, artistic or social projects.

The reason why the research assistants who perceived their leisure time as sufficient spent more time on Internet for gaming, etc. and constantly preferred these activities may be the necessity of sparing the current durations of leisure time for sportive, artistic or similar active recreational activities. Cases that require transportation, equipment, preparation, etc. may be important in preferring such activities. In addition, it makes passive use of Internet more attractive that the research assistants of which majority is on moderate or low income level $(96.5 \%)$ have free or very cheap access to Internet; gyms, swimming pools and other active recreation centers are expensive than their incomes can afford and do not provide ease of use.

It should be ensured that younger research assistants benefit from sportive and artistic facilities in accordance with their interests and under specific conditions and spend time in active and dynamic environments by means of social projects. It was found that majority (73\%) of the research assistants do not have any personal talents or interest to make use of or get busy with during their leisure time. Hence, the most easily accessible activity is Internet. Courses and seminars should be organized to develop research assistants' talent in different branches to stabilize this situation. Moreover, it may be suggested a new institutional social policy of interaction between professionals and also propose the development of leisure activities in groups, to develop professional interactions social with each other. Gaining experiences and skills in the activities such as several sportive, musical, theatric and social projects, this will achieve positive results for both research assistants and the students they will guide.

\section{REFERENCES}

[1] A. Tarcan. Dünden Bugüne İnternet Üzerine Felsefi Yaklaşımlar, İnternet ve Toplum, Anı Yayıncılık, Ankara, 2005.

[2] Ş. Balc1, B. Ayhan. Üniversite öğrencilerinin internet kullanım ve doyumları üzerine bir saha araştırması. Selçuk İletişim, 5(1), 174-197, 2007.

[3] V. Murali, S. George. Lost online: an overview of internet addiction. Advances in Psychiatric Treatment, 13, 24-30, 2007.

[4] K.S.Young. Internet addiction. The emergence of a new clinical disorder. Cyberpsychol Behav, 1, 237- 244,1998.

[5] K.S. Young. Internet addiction a new clinical phenomenon and its consequences. Am Behav Sci, 48, 402-415,2004.

[6] J. Morahan-Martin, P. Schumacher. Incidence and correlates 
of pathological Internet use among college students. Computers in Human Behavior, 16, 13-29, 2000.

[7] R.A. Davis, G.L.Flett, A. Besser. Validation of a new scale for measuring problemeatic Internet use: Implications for pre-employment screening, CyberPsychology \&Behavior, 15, 331-247, 2002.

[8] O. Egger, Ö. Rauterberg. Internet behavior and addiction. Unpublished Master's thesis, Swiss Federal Institute of Technology, Zurich, 1996.

[9] H. Kim, K.E. Davis. Toward a comprehensive theory of problematic Internet use: Evaluating the role of self-esteem, anxiety, flow, and the self-rated importance of Internet activities. Computers in Human Behavior, 25, 490-500, 2009.

[10] R.A.Davis. A cognitive-behavioral model of pathological Internet use. Computers in Human Behavior, 17, 187-195. Doi:10.1016/S0747-5632, 2001.

[11] A.A. Ceyhan, E. Ceyhan. Üniversite Öğrencilerinin Problemli İnternet Kullanım Düzeyleri ile Denetim Odağı, Antisosyal Eğitim ve Sosyal Normlara Uyum Düzeyleri Arasındaki İlişkiler. 16. Ulusal Eğitim Bilimleri Kongresi, Tokat, Gaziosmanpaşa Üniversitesi, 2007.

[12] D.M. Siyez, A. Uzbaş .İnternet bağımlılığı ve psikososyal faktörler. M. Kalkan ve C. Kaygusuz (Ed.), İnternet bağımlılı̆̆ı: Sorunlar ve çözümler içinde. Ankara, Anı Yayınc1lık, 2013.

[13] F. Ekși. Examination of narcissistic personality traits' predicting level of internet addiction and cyber bullying through path analysis. Kuram ve Uygulamada Eğitim Bilimleri, 12, 1694-1706, 2012.

[14] I. Berson, M. Berson. Digital literacy for effective citizenship. Social education, 67(3), 164-167, 2003.

[15] J. Colwell, M. Kato. Investigation of the relationship between social isolation, elf-esteem, aggression and computer game play in Japanese adolescents. Asian Journal of Social Psychology, 6, 149-158, 2003.

[16] C.S. Kerberg. Problem and pathological gambling among college athletes. Annals of Clinical Psychiatry, 17(4), 243-247, 2005.

[17] R.W. Kubey, M.J. .Lavin ,J.R. Barrows. Internet use and collegiate academic performance decrements: Early findings. Journal of Communication, 51(2), 366-382, 2001.

[18] S.E. Caplan. Problematic Internet use and psychosocial well-being: Development of a theory-based cognitive-behavioral measurement instrument. Computers in Human Behavior, 18, 553-575, 2002.

[19] C.A. Anderson, B.J. Bushman. Effects of violent video games on aggressive behaviour, aggressive cognition, aggressive affect, physiological arousal, and prosocial behaviour: A meta-analysis of the scientific literature. Psychosocial Science, 12, 353-359, 2001.

[20] C.K. Yang, B.M. Choe, M. Baity, J.H. Lee , J.S. Cho. SCL $90-\mathrm{R}$ and 16PF profiles of senior high school students with excessive internet use. Canadian Journal of Psychiatry, 50(7), 407-414, 2005.

[21] K.A. Cordes, H.M. İbrahim. Applications in Recreation and Leisure(^3rd ed.). McGraw-Hill: New York, 2003.
[22] S. Karaküçük. .Rekreasyon: Boş zamanları Değerlendirme. Gazi Kitabevi, Ankara, 2008.

[23] R. Koshar. History of Leisure. Berg-Oxford International Publishers, 2002.

[24] K. Ögel. İnternet Bağımlılı̆̆ı: İnternetin Psikolojisini Anlamak ve Bağımlılıkla Başa Çıkmak .İstanbul: İş Bankası Kültür Yayınları, 2012.

[25] T. Bas. How is questionnaire designed, applied and evaluated?. Ankara: Seckin Publishing, 2008.

[26] K. Ögel, F. Karadağ, D. Satgan. Psychometric Properties of the Addiction Profile Index Internet Addiction Form(BAPINT). Klinik Psikofarmakoloji Bülteni. Poster Bildirileri, 22(1), 110, 2012.

[27] J.J. Kandell. Internet addiction on campus: The vulnerability of college students. Cyberpsychology of Behavior, 1, 11-17, 1998.

[28] A.S. Hall, J. Parsons J. Internet addiction: College student case study using best practices in cognitive behavior therapy. Journal of Mental Health Counseling, 23(4), 312-327, 2001.

[29] A.C. Douglas, J.E. Mills, M. Niang, S. Stepchenkova, S. Byun, C. Ruffini C. Internet addiction: Meta-synthesis of qualitive research for the decade 1996-2006. Computers in Human Behavior, 24, 3027-3044, 2008.

[30] M.C. Yıldız, K. Bölükbaş.Internet Kafeler, Gençlik ve Sosyal Sapma, Đnternet ve Toplum, Ed.: A. Tarcan, Anı Yayıncılık, Ankara, 38-54, 2005.

[31] İ.H. Bülbül. Öğretim Elemanlarının İnterneti Kullanma Eğilimleri. Selçuk Ünv. Eğitim Fakültesi, Eğitim Bilimleri Bölümü, 7. Ulusal Eğitim Bilimleri Kongresi, Konya, 9-11 Eylül, 1998.

[32] M. Tel,B. Köksalan B. Günümüzde Yeni Bir Boş Zaman Aktivitesi Olarak İnternet: Öğretim Üyeleri Örneği. Elektronik Sosyal Bilimler Dergisi, 28(8), 262-272, 2009.

[33] Y.J. Choi. Investigating Koreans' internet use patterns and motivations and exploring vulnerability of internet dependency. Unpublished doctoral dissertation, 2001.

[34] B. Oguz, N.Zayim, D. Özel, O. Saka. Tıp öğrencilerinin internette bilișsel durumları. Akademik Bilișim 2008 Konferansında sunulan bildiri, Çanakkkale Onsekiz Mart Üniversitesi, Çanakkale, 2008.

[35] S.M. Li, T.M. Chung. Internet function and Internet addictive behavior. Computers in Human Behavior, 22(6), 1067-1071, 2006.

[36] G.D. Weitzman. Family and individual funstioning and computer/internet addiction. Unpublished doctoral dissertation, 2000.

[37] Ö. Çakır-Balta, M.B. Horzum. Web tabanlı öğretim ortamındaki öğrencilerin internet bağımlılığını etkileyen faktörler. Ankara Üniversitesi Eğitim Bilimleri Fakültesi Dergisi, 41(1), 187-205, 2008.

[38] M.D. DiNicola. Pathological internet use among college students: The prevalence of pathological internet use and its correaltes. Doctoral dissertation, Ohio University, 2004.

[39] R.A. Everhard. Charactersictics of pathological internet users: An examination of on-line gamers. Unpublished doctoral dissertation, 2000 . 
[40] K. Scherer. College life online: healthy and unhealthy Internet use. Journal of College Student Development, 38, 655-664, 1997.

[41] TÜİK (TSI: Turkish Statistics Ins.). Hane Halkı Bilişim Teknolojileri Kullanım Araştırması, Erişim tarihi: 15.08.2015 http://www.tuik.gov.tr/, 2014.

[42] Alternatif Bilişim Derneği. Türkiye'de İnternet'in Durumu. Alternatif Bilişim Derneği, İstanbul, 2012.

[43] G. Torkildsen. Leisure and Recreation Management, Routledge-Taylor \&Francis, 2005.

[44] K. Ögel, F. Karadağ, C. Evren, D.T. Gürol. Bağımlılık Profil İndeksi(BAPİ) Uygulama Rehberi. Yeniden Yayınları, İstanbul, 2012.

[45] R. Kraut, M. Patterson, V. Lundmark, S. Kiesler, T. Mukonpadhya, W. Scherlis. Internet paradox: A social technology that reduces social involvement and psychological well-being. American Psychologist, 53(9), 1017-1031, 1998.

[46] S. Sum, R. M. Mathews, I. Hughes, A. Campbell. Internet use and loneliness in older adults. CyberPsychology \& Behavior, 11(2), 208-211, 2008.

[47] L. Milani, D. Osualdella, P.Di Blasio. Quality of interpersonal relationships and problematic Internet use in adolescence. Cyber Psychology \& Behavior, 12(6), 681-684, 2009.

[48] K. S. Young. Internet addiction: Evaluation and treatment. Student British Medical Journal, 7(1), 105-111,1999.

[49] J. M. Parsons. An examination of massively multiplayer online role-playing games as a facilitator of Internet addiction. (Ph.D., the University of Iowa). ProQuest Dissertations and Theses, Retrieved from http://search.proquest.com.ezp2.lib.umn.edu.ezp1.lib.umn.ed $\mathrm{u} /$ docview/304989911? accountid=14586, 2005. 